\title{
The Price Impact of House Refurbishment Estimated by Geographically Weighted Regression and Hedonic Pricing Model
}

\author{
Peddy $^{1}$, Pi-Ying, Lai, Dominique Achour-Fischer ${ }^{2}$ \\ ${ }^{1}$ Department of Real Estate Management, National Pingtung University, Taiwan \\ ${ }^{2}$ Addis Ababa University, Ethiopia \\ 11 piying@mail.nptu.edu.tw
}

\begin{abstract}
Geographically Weighted Regression (GWR) is a technique that extends the traditional regression framework by allowing spatial parameters to be explicitly estimated. This paper provides a brief description of the Geographically Weighted Regression used here to value the effect of residential housing refurbishment in the City of Kaohsiung (Taiwan). The GWR results are then compared to a standard hedonic pricing estimation model applied to the same data set. What is intended here is to illustrate the use of a better tool for the identification of the spatial price impact of housing improvement investments in the metropolitan area. More generally, the paper confirms that spatial-adaptable models are required to measure the impact of investments in mixed and fuzzy goods.
\end{abstract}

Keywords: House Refurbishment, Hedonic Price, Geographically Weighted Regression, Mixed Fuzzy Public Goods.

\subsection{INTRODUCTION}

The general issue tackled in this paper is the evaluation of price-effects of the investment in public mixed fuzzy goods(Achour-Fischer,1980). Most of similar applications described in the synoptic literature review presented below apply to public transports, urban infrastructures and renovation or refurbishment projects. Here, such a Taiwanese refurbishment project will be described and treated using a Geographically Weighted Regression analysis (GWR).

New Taipei City and Taipei City have put in place various policies in order to stimulate urban redevelopment, refurbishment and urban conservation. Most of these policies were justified by the hypothesis that such public investment would add value (and thus property taxes) to the existing housing stock. This hypothesis may have been justified in a city like Taipei where urban growth leads tocontinuous appreciation. However, these positive external effects may not necessarily apply to Central or Southern Taiwanese cities that have not benefited for the same level of economic dynamism. 
This study uses a geographically weighted regression analysis on a sample of real transactions from Kaohsiung city in Taiwan to determine, the price effect of refurbishment and housing rehabilitation investments. There are five sections in this study: 1.0) Introduction 2.0) A Synoptic Review of The Literature 3.0) Research Method 4.0) Empirical Analysis and 5.0) Conclusion

Most of the existing literature confirms the positive externalities conferred by investments made to improve the quality of surrounding housing and neighbourhood. Externalities may be resulting from improved landscaping, stigma removal, better access to natural traits (parks, river, view, etc.) or they can result from quality improvement of building and/or urban infrastructures. These positive externalities obtain whether these improvements comes from individual and independent refurbishment efforts or if they are the result of public renovation projects. Such mixed forms of investments can also be qualified as 'fuzzy' because their effects are geographically diffused, difficult to delineate and spatially differentiated: some sectors will benefits, some sectors will not, and some sectors may show negative price effects.

\subsection{A SYNOPTIC REVIEW OF THE LITERATURE}

The last 15 years of similar research confirm the basic intuition that part of the positive externalities will be-to some extent-capitalised in housing values. It also confirms the 'fuzziness' or such effects: externalities are spatially diffused and not uniformly positive.

In the last thirty year, many literatures had addressed the econometric treatments of externalities. However, it is observed that increasing hedonic models have been replaced by spatially differentiating models, such as geographically weighted regression modelling.

Table 1: Literature Review of Regression Model

\begin{tabular}{|c|c|c|}
\hline Year & Authors & Major conclusions \\
\hline 2016 & Haotian Zhong, Wei Li & $\begin{array}{l}\text { Analysis of single-family and multi-family } \\
\text { property sale transactions in Los Angeles (CA) } \\
\text { during } 2003 \text { and } 2004 \text {. Demonstrate the superiority } \\
\text { of spatial hedonic models (Spatial Durbin models } \\
\text { and GWR models). The results confirm the } \\
\text { heterogeneous effects of public transport } \\
\text { amenities. }\end{array}$ \\
\hline 2016 & $\begin{array}{l}\text { Jing Yao, A. Stewart } \\
\text { Fotheringham }\end{array}$ & $\begin{array}{l}\text { The paper applies a spatial-temporal approach, } \\
\text { semiparametric geographically weighted } \\
\text { regression (GWR), to explore the relationships } \\
\text { between house prices and associated determinants. } \\
\text { The mixed modelling technique provides better } \\
\text { results than standard approaches. }\end{array}$ \\
\hline 2015 & $\begin{array}{l}\text { Mohd Faris Dziauddin, Neil } \\
\text { Powe, Seraphim Alvanides }\end{array}$ & $\begin{array}{l}\text { Use GRW to measure the impact of a light rail } \\
\text { transit system (LRT) on residential property values } \\
\text { in Greater Kuala Lumpur, Malaysia. Once again, } \\
\text { the results 1) illustrate the public transport } \\
\text { heterogeneous price effects: some favorable some }\end{array}$ \\
\hline
\end{tabular}




\begin{tabular}{|c|c|c|}
\hline & & $\begin{array}{l}\text { unfavourable and 2) confirm the superiority of } \\
\text { GRW over non-spatial hedonic analysis. }\end{array}$ \\
\hline 2014 & $\begin{array}{l}\text { BenedettoManganelli, } \\
\text { PiergiuseppePontrandolfi, } \\
\text { AntonelloAzzato, } \\
\text { BeniaminoMurgante }\end{array}$ & $\begin{array}{l}\text { Geographically weighted regression (GWR) has } \\
\text { been used in analysing the city of Potenza } \\
\text { (Basilicata, southern Italy) housing market, in } \\
\text { order to identify homogeneous areas and to define } \\
\text { the marginal contribution that a single location } \\
\text { gives to the market value of the property. } \\
\text { Demonstrates the potential advantage of GWR to } \\
\text { improve mass valuation models. }\end{array}$ \\
\hline 2012 & Yau, Yung & $\begin{array}{l}\text { The paper compares the impact of redevelopment } \\
\text { with building rehabilitation on house prices in } \\
\text { Hong Kong. Two housing improvement projects in } \\
\text { the old urban area are targeted for investigation } \\
\text { using hedonic price analysis. Yet, no significant } \\
\text { positive net externalities are identified from both } \\
\text { redevelopment and rehabilitation. }\end{array}$ \\
\hline 2010 & B Huang. B Wu. M. Barry & $\begin{array}{l}\text { Use of an extended GWR model, geographically } \\
\text { and temporally weighted regression (GIWR), has } \\
\text { been developed to deal with both spatial and } \\
\text { temporal nonstationary simultaneously on } \\
\text { residential housing sales in the city of Calgary, } \\
\text { Canada, from } 2002 \text { to } 2004 \text {. The introduction of } \\
\text { time in the coefficient matrices improves the } \\
\text { performance of GTWR over non-temporal GWR. }\end{array}$ \\
\hline 2007 & $\begin{array}{l}\text { Bitter, GF Mulligan, S } \\
\text { Dall'erba }\end{array}$ & $\begin{array}{l}\text { Comparison of two approaches to examine spatial } \\
\text { heterogeneity in housing attributes prices within } \\
\text { the Tucson, Arizona housing market: the spatial } \\
\text { expansion method and geographically weighted } \\
\text { regression (GWR). Confirms that the marginal } \\
\text { price of key housing characteristics varies over } \\
\text { space. GWR outperforms the spatial expansion } \\
\text { method in terms of explanatory power and } \\
\text { predictive accuracy. }\end{array}$ \\
\hline 2006 & Hongbo Du, Corinne Mulley & $\begin{array}{l}\text { The use GRW allows to demonstrate that transport } \\
\text { accessibility may have a positive effect on land } \\
\text { value in some areas but a negative or no effect in } \\
\text { others }\end{array}$ \\
\hline 2003 & $\begin{array}{l}\text { K.W. Chau, S.K. Wong,A.Y.T. } \\
\text { Leung. C.Y. Yiu }\end{array}$ & $\begin{array}{l}\text { Rehabilitation of large-size residential } \\
\text { communities in Hong Kong lead to a9\% increases } \\
\text { in the property market values. This value } \\
\text { appreciation exceeds the refurbishment costs. }\end{array}$ \\
\hline
\end{tabular}


The most directly relevant treatment is the one by K.W Chau and al. (2003) on Hong Kong renewal data. They concluded that once revealed, renewal projects have positive hallo effects that depends on the size of the project and also depends on the number of commercial activities included in the project contour. However, more interestingly, they also illustrate some negative impact on the surrounding areas (notably for older buildings). They attribute this negative hallo effect to the fact that urban renewal may reduce the redevelopment option values of properties not included in the boundaries of urban renewal.

Some other pertinent papers studied various externalities effects on housing price by spatial hedonic price model (Haotian Zong \& Wei Li(2016), Jing Yao \& Stewart Fotheringham (2016), Yao Chen \& Kayvan Karimi (2015)).

However, no empirical study of housing improvement investments has been attempted for Taiwan and more specifically for Taiwanese cities that may not have enjoyed the same pressure on housing and land prices.

The Kaohsiung program under investigation could not be strictly defined as an urban renewal programme, but rather as a building refurbishment effort that included government subsidies to supplement owner equity contribution. The project started in 2006 in a limited area in close proximity of a subway station (KMRT). Over 200 buildings aged over 20 years were rehabilitated to the tune of 42 million Taiwan Dollars over the six-year period. The building islow-rise types ( 2 \& 3 storeys) and the amount of subsidies per unit was not sufficient to cover the costs. Private investment was thus required but the typical "free riding" behaviour did not occur since the effort became compulsory for the urban sector.

Table 2: Kaohsiung refurbishment program

\begin{tabular}{|c|c|c|c|c|}
\hline \multirow{2}{*}{ Year } & \multirow{2}{*}{$\begin{array}{c}\text { Number of } \\
\text { buildings } \\
\text { renovated }\end{array}$} & Total Subsidy in TNT & \multicolumn{2}{|c|}{ Cost per Building } \\
\hline 2006 & 12 & 400,000 & 33,333 & $1,066.67$ \\
\hline 2007 & 10 & $2,718,900$ & 271,890 & $8,304.52$ \\
\hline 2008 & 32 & $4,777,800$ & 149,306 & $4,921.10$ \\
\hline 2009 & 69 & $21,480,296$ & 311,309 & $9,018.21$ \\
\hline 2010 & 46 & $5,137,200$ & 111,678 & $3,475.83$ \\
\hline 2011 & 53 & $7,618,000$ & 143,736 & $4,859.22$ \\
\hline Total & 222 & $42,132,196$ & 1021,252 & 31645.60 \\
\hline
\end{tabular}

*Based on exchange rates that prevailed during each year 


\subsection{RESEARCH METHOD}

This paper attempts to identify the externality effect of sectorial urban renewal on property values in Kaohsiung city in Taiwan. It aims to verify if the Kaohsiang data follows the intuition and claims of previous studies that states housing values are higher in areas that have benefited from urban renewal efforts.

A local analysis was undertaken using one of the tools developed in spatial Econometrics and Geographical Information statistics. More specifically,we intend to demonstrate the relevance of the Geographical Weighted regression (GWR). The development of this technique can be mostly being attributed to the "Ireland nexus"; S. Fotheringham Chris Brunsdon and Martin Charlton (Brunsdon et al., 1996; Fotheringham et al., 1997, Charlton et al., 1998).

\subsection{Geographically Weighted Regression}

In a typical regression analysis, it is assumed that independent variables have a uniform influence on the dependent variable (e.g. land price $=\mathrm{f}$ (distance to the city centre). The strength of this influence was measured by the regression coefficients of the variable "distance". Implicitly we thus assume that the same coefficient is valid for points located at the same distance from the central. In other word, the effect of distance is uniform and not affected by the specific location of the observed land lots. Thus, we assume stationarity: the effect of the independent variables on the dependent variable remains constant throughout time (in time series) and/or over space (in spatial treatments).In this example, it is not possible to observe any difference in price per square meter for a lot located next to a garbage dump or located next to a beautifully landscaped park.

Standard econometric treatments often try to use additional variables or some form of dummy variables that would allow spatial differentiation. However, beyond many econometric estimation problems, this approach cannot take into account that the location of each lot will have a different influence. Thus, using a dummy variable for "proximity to a park" does not allow you to show that "proximity" to the park can't differentiate between "view to the park", "further away from the park", "wrong side of the park", "too close to the park entrance", etc.

Another difficulty in trying to refine the cross sectional analysis of localised data is the problem of spatial dependence: even within a limited sector, the value of a variable in point $i$ am dependent on the values of neighbouring observations at nearby locations.Thus, to simplify, the standard regression models as mostly used in hedonic formulations are not appropriate to deal with spatial differentiation and spatial dependency. They need independent variables (and errors) and stationary coefficients.

Another source of spatial non-stationarity, albeit less obvious is that the basic model (typically a hedonicsimple format) may be poorly specified : missing relevant variables suffer from blatant collinearity or even have chosen the wrong functional form.As usual, any form of misspecification lead to unstable coefficients. Here the parametric instability would apply from on location to another and, generally with hedonic models, the instability would apply from one period to the next. This is why; in general, simplistic hedonic models cannot be used reliably in predictive modelling.

GWR models do not require stationarity assumptions; in fact, they are designed to allow for nonstationarity by measuring different impacts in different locations. With the development and generalisation of Geographical Information Systems - where each location within as sample space 
can be precisely characterised by any set of variables - it became possible to run regressions for each specific point and thus to measure the specific impact of each variable.

Once the coordinate of a point is identified, a point-specific regression can be run and the resulting coefficient of determination $\mathrm{R}^{2}$ (the ratio of the variances of predicted value of the dependent variable to the variance of the independent variables) calculated. The point-specific $t$ test of significance can also be estimated.The results $\left(\mathrm{R}^{2}\right.$ and $\mathrm{t}$ tests) can be mappedto illustrate the magnitude and significance of point-specific effects.

Fortunately, access to the appropriate instruments to perform such analysis with, for example, a GWR module incorporated in the ArcGIS package is now available. Another package is also available from the GWR initiators. (The Ireland Nexus).

\subsection{GWR More Formally}

We could compare a standard linear regression model such as:

$$
Y_{i}=a_{\mathrm{o}}+\sum a_{i} x_{i}+\varepsilon_{i}
$$

The constant term applies uniformly for each value of xi variable. This model is the basis of the traditional hedonic treatment of multi-traits goods and thus the basis of hedonic property valuation models.

However, the effects of investment in mixed fuzzy goods are not homogeneous over space and thus that the coefficients estimated in hedonic models cannot be location specific. The GWR is a technique that extends the traditional regression framework. The concepts behind this approach are discussed by Fotheringham and Brunsdon (1996) and further illustrated by Fotheringham (1997) and Fotheringham and Brunsdon (1999).

An alternative location-specific model can be written as shown in equation (2):

$$
Y_{i}=a_{0 i}+\sum_{k} a_{k i} X_{i k}+\varepsilon_{i}
$$

Where $a_{\mathrm{ki}}$ represents the value of $a_{\mathrm{k}}$ at point ${ }^{i}$ and where each local observation ${ }^{i}$ has a different coefficient and a different constant

The ${ }^{i}$ location is further denoted by its coordinates $u$ and $v$ and the $k\left(u_{i}, v_{i}\right)$ functions is meant to model a continuous decay function where the effect of distance is exponentially decreasing.

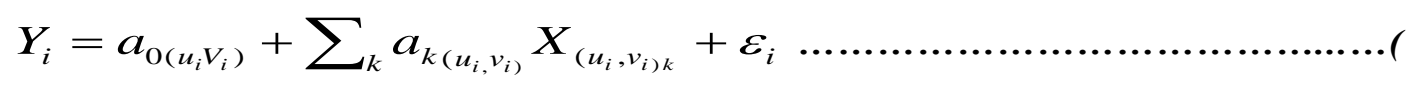

(Brunsdon et al., 1996; Fotheringham et al., 1998) 
In matricial form the standard format for the coefficients would be:

$$
\mathrm{A}=\left(\mathrm{X}^{\prime} \mathrm{X}\right)^{-1} X^{\prime} Y
$$

(4)

With the GWR format, the coefficients would be obtained by solving:

$$
\mathrm{A}=\left(\mathrm{X}^{\prime} W\left(u_{i} v_{i}\right) X\right)^{-1} X^{\prime} W Y
$$

Where the relevant matrix is now:

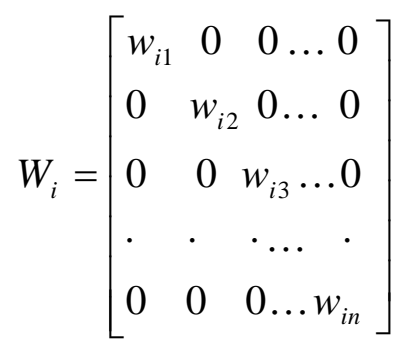

Where $W_{\text {in }}$ denotes the weight of the data from transaction $\mathrm{n}$ on the calibration of the model around point $i$ (in this case the point $i$ will be a property which are collected). The weights are defined as continuous functions of distance so that the closer a data point is to the calibration point, the greater its weight is in the estimation of the parameters for that point. An alternative weighting procedure is a discrete one, in which all data points within a prescribed distance from $i$ are given a weight of one and all points beyond this distance are given a weight of 0 .

However, this seems an unrealistic representation since most price diffusion processes are continuous. The selection of a particular continuous weighting function does not appear to be very important (Fotheringham et al., 1998) and in this instance the weighting function selected is a Gaussian one so that:

$$
W_{i j}=\exp \left(-\left(d_{i j} / h_{i}\right)^{2}\right)
$$

......................................................... (7)

Where $d_{i}$ is the distance between transaction $i$ and transaction ${ }^{j}$ and $h_{i}$ is a bandwidth that affects the distance-decay of the weighting function. Too large a bandwidth will produce a flat surface with little spatial variation. Too small a bandwidth will result in estimation problems with some of the local regressions. Brunsdon et al.(1996) and Fotheringham et al.(1997,1998) describe how the bandwidth can be calibrated in the model. 


\subsection{EMPIRICAL ANALYSIS}

\subsection{Data}

Data came from4,096sales that took place from 2008 to 2009 in Kaohsiung City. The variables are described and coded in Table 3 below.

Table 3: Definition of Variables

\begin{tabular}{|c|c|c|c|}
\hline Variables & Definition & Units & $\begin{array}{l}\text { Expected } \\
\text { sign ofthe } \\
\text { coefficient }\end{array}$ \\
\hline \multicolumn{4}{|l|}{ Dependent variable } \\
\hline Sale price & Natural logarithm of sale price & NT\$ & \\
\hline \multicolumn{4}{|l|}{ Independent variables } \\
\hline Land area & Size of the lot & $\mathrm{m} 2$ & + \\
\hline Building area & $\begin{array}{l}\text { Total building floor area of property. } \\
\text { Larger building floor areas mean higher } \\
\text { building costs. }\end{array}$ & $\mathrm{m} 2$ & + \\
\hline Age & $\begin{array}{l}\text { Property age } \\
\text { Directly reflect depreciation and } \\
\text { maintenance status. Usual property } \\
\text { longevity is } 50-60 \text { years with structural } \\
\text { strength at a peak of } 2-3 \text { years after } \\
\text { construction and declining later. }\end{array}$ & Years & - \\
\hline Totflor & $\begin{array}{l}\text { Total numbers of floors } \\
\text { More floors, higher costs. }\end{array}$ & Numbers & + \\
\hline $\begin{array}{l}\text { Type of structure } \\
\text { (S1) }\end{array}$ & $\begin{array}{l}\text { The various types are: mixed steel } \\
\text { reinforcement concrete(coded 1), reinforced } \\
\text { brick, stone, metal, and light steel frame } \\
\text { made (coded 0) }\end{array}$ & $\begin{array}{l}\text { Dummy } \\
\text { Variables }\end{array}$ & + \\
\hline RoadW & $\begin{array}{l}\text { The wider the road faced by the building, } \\
\text { the higher house price. }\end{array}$ & Meters & + \\
\hline Zoning (Z1) & $\begin{array}{l}\text { Commercial zone (coded } 1) \text {, residential } \\
\text { zone }(\text { coded } 0)\end{array}$ & $\begin{array}{l}\text { Dummy } \\
\text { Variables }\end{array}$ & + \\
\hline Location & $\begin{array}{l}\text { There are } 11 \text { districts in Kaohsiung City: } \\
4 \text { districts (Xiaogang, Tsoying, Nanzih, and }\end{array}$ & $\begin{array}{l}\text { Dummy } \\
\text { Variables }\end{array}$ & + \\
\hline
\end{tabular}




\begin{tabular}{|c|c|c|c|}
\hline & $\begin{array}{l}\text { Cijin) are suburbs (Coded 0) } \\
7 \text { districts (Yancheng, Gushan, Sanmin, } \\
\text { Lingya, Xinxing, Qianjin and Cianjhen) are } \\
\text { Urban (Coded 1) }\end{array}$ & & \\
\hline Positioning (R1) & $\begin{array}{l}\text { Type of street configuration: } \\
\text { Cul-de-Sac (coded } 0) \\
\text { Street corner (Coded } 1)\end{array}$ & $\begin{array}{l}\text { Dummy } \\
\text { Variables }\end{array}$ & + \\
\hline Property type (T1) & $\begin{array}{l}\text { Property type: } \\
\text { Townhouse and apartment (Coded 1); } \\
\text { Commercial store (Coded } 0) \text {. } \\
\text { Typically, commercial space is more } \\
\text { expensive than townhouses and apartments. }\end{array}$ & $\begin{array}{l}\text { Dummy } \\
\text { Variables }\end{array}$ & - \\
\hline Refurbishment (A2) & $\begin{array}{l}\text { Properties which are within } 100 \text { meters } \\
\text { from the refurbishing zone are coded } 1 \text {, } \\
\text { others are coded } 0 \text {. }\end{array}$ & $\begin{array}{l}\text { Dummy } \\
\text { Variables }\end{array}$ & + \\
\hline Rehabilitation (A3) & $\begin{array}{l}\text { Properties located within the designated } \\
\text { rehabilitation area are coded } 1 \\
\text { Other properties are coded } 0 .\end{array}$ & $\begin{array}{l}\text { Dummy } \\
\text { Variables }\end{array}$ & + \\
\hline
\end{tabular}

\subsection{Hedonic Price Modelling}

A standard hedonic model was run on the data collected. The resulting $\mathrm{R}^{2}$ value was $30.6 \%$ and all variables entered were statistically significant at $95 \%$ level.The results of the analysis are shown in the Table 4. Most of the coefficients are highly significant.The signs of the coefficients are in conformity with expectations except for the number of floors and type of structure.

Table 4: Hedonic estimation of housing prices

\begin{tabular}{|l|c|c|c|c|c|c|c|}
\hline \multirow{2}{*}{ Variables } & $\boldsymbol{\beta}$ value & $\begin{array}{c}\text { standard } \\
\text { error }\end{array}$ & T-value & P-value & \multirow{2}{*}{ CI } & \multicolumn{2}{c|}{$\begin{array}{c}\text { Multi } \\
\text { correlation }\end{array}$} \\
\hline Constant & 10.909 & .033 & 331.831 & $.000^{* * *}$ & 1 & & \\
\hline Landarea & $6.124 \mathrm{E}-04$ & .000 & 9.469 & $.000^{* * *}$ & 2.696 & .805 & 1.242 \\
\hline Building area & $3.574 \mathrm{E}-04$ & .000 & 5.167 & $.000^{* * *}$ & 3.056 & .579 & 1.728 \\
\hline Age & $-9.476 \mathrm{E}-03$ & .001 & -15.720 & $.000^{* * *}$ & 3.202 & .369 & 2.707 \\
\hline Totflor & $-1.771 \mathrm{E}-02$ & .001 & -13.743 & $.000^{* * *}$ & 3.536 & .529 & 1.890 \\
\hline Road-w & $3.829 \mathrm{E}-03$ & .001 & 7.356 & $.000^{* * *}$ & 4.883 & .797 & 1.255 \\
\hline
\end{tabular}




\begin{tabular}{|l|c|c|c|c|c|c|c|}
\hline Z1: Zoning & $4.016 \mathrm{E}-02$ & .013 & 3.173 & $.002 * * *$ & 5.597 & .867 & 1.153 \\
\hline $\begin{array}{l}\text { S1: Type of } \\
\text { structure }\end{array}$ & -.390 & .017 & -22.731 & $.000 * * *$ & 6.137 & .532 & 1.878 \\
\hline $\mathrm{R} 1:$ Positioning & $7.572 \mathrm{E}-02$ & .013 & 5.880 & $.000 * * *$ & 6.674 & .719 & 1.392 \\
\hline T1: Building type & -.164 & .017 & -9.798 & $.000 * * *$ & 8.337 & .784 & 1.275 \\
\hline $\begin{array}{l}\text { L1: } \\
\text { Urban/Suburban }\end{array}$ & $3.438 \mathrm{E}-02$ & .013 & 2.617 & $.009 * * *$ & 9.371 & .765 & 1.307 \\
\hline $\begin{array}{l}\mathrm{N}=4,096 ; \mathrm{R}^{2}=0.306 ; \text { Adj. } \mathrm{R}^{2}=0.304 ; \mathrm{F}=142.916 ; \mathrm{P}=0.000 \\
\text { Notes: } 1 . * \text { significant at 0.1\% level ** significant at 5\% level;***significant at } 1 \% \text { level; }\end{array}$ \\
\hline
\end{tabular}

Now, to test the effect of differentiated spatial price effect, we add the proximity to refurbishment factor (A2) to the determinant vector. (A2 = within $100 \mathrm{~m}$ of refurbishing zone). See the Table 5. In addition, the Table 6 is based on the inclusion in the rehabilitation zone (A3).

Table 5: Model I - Hedonic estimation of housing prices including the proximity to refurbishment (A2)

\begin{tabular}{|c|c|c|c|c|c|c|c|}
\hline \multirow{2}{*}{ Variables } & \multirow{2}{*}{$\beta$ value } & \multirow{2}{*}{$\begin{array}{l}\text { standard } \\
\text { error }\end{array}$} & \multirow[t]{2}{*}{ T-value } & \multirow{2}{*}{ P-value } & \multirow[t]{2}{*}{ CI } & \multicolumn{2}{|c|}{$\begin{array}{c}\text { Multi } \\
\text { correlation }\end{array}$} \\
\hline & & & & & & error & VIF \\
\hline Constant & 10.876 & .032 & 345.039 & $.000 * * *$ & 1 & & \\
\hline Landarea & $5.663 \mathrm{E}-04$ & .000 & 9.279 & $.000 * * *$ & 2.716 & .814 & 1.229 \\
\hline Building area & $4.408 \mathrm{E}-04$ & .000 & 6.610 & $.000 * * *$ & 3.042 & .589 & 1.699 \\
\hline Age & $-1.056 \mathrm{E}-02$ & .001 & -19.059 & $.000 * * *$ & 3.162 & .379 & 2.637 \\
\hline Totflor & $-1.383 \mathrm{E}-02$ & .001 & -11.660 & $.000 * * *$ & 3.547 & .595 & 1.680 \\
\hline Road-w & $4.974 \mathrm{E}-03$ & .000 & 10.010 & $.000 * * *$ & 5.035 & .814 & 1.228 \\
\hline Z1: Zoning & $2.877 \mathrm{E}-02$ & .012 & 2.339 & $.019 * *$ & 5.554 & .852 & 1.173 \\
\hline S1: Type of structure & -.402 & .016 & -24.775 & $.000 * * *$ & 5.608 & .544 & 1.839 \\
\hline R1: Positioning & $2.925 \mathrm{E}-02$ & .012 & 2.445 & $.015 * *$ & 6.296 & .757 & 1.321 \\
\hline T1: Building type & -.205 & .016 & -12.521 & $.000 * * *$ & 8.253 & .802 & 1.246 \\
\hline L1: Urban/Suburban & .115 & .012 & 9.913 & $.000 * * *$ & 9.511 & .727 & 1.376 \\
\hline $\begin{array}{l}\text { A2: distance from } \\
\text { refurbishment area }\end{array}$ & .108 & .035 & 3.066 & $.002 * *$ & 20.273 & .983 & 1.017 \\
\hline
\end{tabular}


Table 6:Model II - Hedonic estimation of housing prices adding the inclusion in the rehabilitation zone (A3)

\begin{tabular}{|c|c|c|c|c|c|c|c|}
\hline \multirow[t]{2}{*}{ Variables } & \multirow[t]{2}{*}{$\beta$ value } & \multirow{2}{*}{$\begin{array}{c}\text { standard } \\
\text { error }\end{array}$} & \multirow[t]{2}{*}{ T-value } & \multirow[t]{2}{*}{ P-value } & \multirow[t]{2}{*}{ CI } & \multicolumn{2}{|c|}{$\begin{array}{c}\text { Multi } \\
\text { correlation }\end{array}$} \\
\hline & & & & & & error & VIF \\
\hline Constant & 10.882 & .031 & 345.521 & $.000 * * *$ & 1 & & \\
\hline Landarea & $5.676 \mathrm{E}-04$ & .000 & 9.317 & $.000 * * *$ & 2.772 & .814 & 1.229 \\
\hline Building area & $4.105 \mathrm{E}-04$ & .000 & 6.140 & $.000 * * *$ & 2.958 & .583 & 1.714 \\
\hline Age & $-1.071 \mathrm{E}-02$ & .001 & -19.318 & $.000^{* * *}$ & 3.233 & .378 & 2.648 \\
\hline Totflor & $-1.432 \mathrm{E}-02$ & .001 & -12.057 & $.000 * * *$ & 3.568 & .591 & 1.692 \\
\hline Road-w & $4.533 \mathrm{E}-03$ & .001 & 8.974 & $.000 * * *$ & 5.090 & .785 & 1.274 \\
\hline Z1: Zoning & $2.834 \mathrm{E}-02$ & .012 & 2.310 & $.021 * *$ & 5.603 & .854 & 1.172 \\
\hline S1: Type of structure & -.399 & .016 & -24.622 & $.000^{* * *}$ & 5.626 & .543 & 1.840 \\
\hline R1: Positioning & $3.130 \mathrm{E}-02$ & .012 & 2.621 & $.009 * * *$ & 6.395 & .756 & 1.322 \\
\hline T1: Building type & -.206 & .016 & -12.638 & $.000^{* * *}$ & 8.316 & .802 & 1.247 \\
\hline L1: Urban/Suburban & .125 & .012 & 10.693 & $.000 * * *$ & 9.533 & .716 & 1.396 \\
\hline $\begin{array}{l}\text { A3 :Inclusion in } \\
\text { Rehabilitation zone }\end{array}$ & .124 & .025 & 5.029 & $.000^{* * *}$ & 20.346 & .920 & 1.087 \\
\hline
\end{tabular}

\subsection{Geographically Weighted Regression Analysis}

The results of two GWR estimation are now presented: Model I analyses 78 transactions that have occurred within 100 meters of the grant-approved area (identification the proximity effect).

Model II analyses 175 transactions located in designated areas and non-major designated areas (identification of the inclusion effect).

\subsubsection{Model I of Geographically Weighted Regression: the proximity effect.}

Based on real grant-approved project for rehabilitation, 78 transaction cases located within 100 meters from the grant-approved area were used. The result is that all relevant variables have a significant effect on property price (except the land-use variable). However, the adjusted coefficient of determination is less than $37 \%$ (meaning that $63 \%$ of price variation is due to factors other than the ones that are used here). 
Table 7 :Geographically Weighted Regression on Model I

\begin{tabular}{|c|c|c|c|}
\hline \multicolumn{4}{|c|}{ GRW Estimation results for Model I (Distance from refurbishment) } \\
\hline Parameter & Estimated & Stand Error & t-Value \\
\hline \multicolumn{4}{|c|}{ The dependent variable is the natural log of transaction price } \\
\hline Intercept & 10.8706 & 0.0454 & $239.2662 * *$ \\
\hline \multicolumn{4}{|l|}{ Independent variables } \\
\hline Land area & 0.0005 & 0 & $5.8229 * * *$ \\
\hline Building Area & 0.0006 & 0.0001 & $5.6262 * * *$ \\
\hline Property age & -0.0102 & 0.0008 & $-13.1063 * * *$ \\
\hline Number of floors & -0.0117 & 0.0016 & $-7.1201 * * *$ \\
\hline Fronting road width & 0.0038 & 0.0007 & $5.3095 * * *$ \\
\hline Z1: Zoning dummy $($ Commercial $=1$, Residential $=0)$ & 0.0356 & 0.0175 & $2.0406 * *$ \\
\hline S1: Structure type (Reinforced steel $=1$, Light steel frame, brick, stone $=0$ ) & -0.4084 & 0.0232 & $-17.5682 * *$ \\
\hline R1: Positionning (Corner lot $=1$, Others $=0$ ) & 0.0151 & 0.0171 & $0.8853 * *$ \\
\hline T1: Buiding type (apartments or town house $=1$, Store dwelling $=0$ ) & -0.1968 & 0.0234 & $-8.3955 * *$ \\
\hline L1: Location (Urban $=1$, Suburban $=0$ ) & 0.1116 & 0.0166 & $6.7294 * *$ \\
\hline A2: Refurbishment status location (Whitin $100 \mathrm{~m}$ from grant area $=1$, outside $=0$ ) & 0.0899 & 0.0482 & $1.8689 * *$ \\
\hline Global & 0.291 & GWR & 0.371 \\
\hline adjusted $\mathrm{R}^{2}$ & $28.70 \%$ & adjusted $\mathrm{R}^{2}$ & $36 \%$ \\
\hline Samples & 4,096 & Samples & 4,096 \\
\hline
\end{tabular}

Table 8 reports the result of a Monte-Carlo run used to estimate non-stationarity effects. The variable with a low $\mathrm{p}$ (below the critical values) is non-stationary, which means that it is significantly determined by its spatial location. It canbe concluded that Building Area, Property Age, R1, T1 and L1 have differentiated impacts on housing prices.

Table 8: Non-stationary variables in Model I

\begin{tabular}{|l|c|}
\hline \multicolumn{1}{|c|}{ Estimating stationarity of space variables } & p -Value \\
\hline Constant & $0.00000^{* *}$ \\
\hline Land area & 0.83 \\
\hline Building Area & $0.03000^{*}$ \\
\hline Property age & $0.00000^{* * *}$ \\
\hline Number of floors & 0.18 \\
\hline Fronting road width & 0.95 \\
\hline Z1: Zoning dummy (Commercial $=1$, Residential $=0$ ) & 0.34 \\
\hline S1: Structure type (Reinforced steel $=1$, Light steel frame, brick, stone $=0)$ & 0.12 \\
\hline R1: Positionning (Corner lot $=1$, Others $=0$ ) & $0.00000^{* * *}$ \\
\hline T1: Buiding type (apartments or town house $=1$, Store dwelling $=0$ ) & $0.01000^{* *}$ \\
\hline L1: Location (Urban $=1$, Suburban $=0)$ & $0.00000^{* * *}$ \\
\hline A2: Refurbishment status location $($ Whitin 100 m from grant area $=1$, outside $=0$ ) & 0.98 \\
\hline Notes: $1 . *$ significant at $0.1 \%$ level $* *$ significant at $5 \%$ level;***significant at $1 \%$ level; & \\
\hline
\end{tabular}




\subsubsection{Model II of Geographically Weighted Regression: The Rehabilitation Zone Inclusion Effect}

175 properties sold within the designated rehabilitation zonewere now tested.Again, all variables have a significant effect on property price.The adjusted $\mathrm{R}^{2}$ for overall model is now $50 \%$ (See Table 9). And, here again the same pattern on non-stationarity, and thus of spatial heterogeneity of the price-effects, can be observed (Table 10).

Table 9: Model II of Geographically Weighted Regression

\begin{tabular}{|c|c|c|c|}
\hline \multicolumn{4}{|c|}{ GRW Estimation results for Model II (Inclusion in the rehabiliation zone). } \\
\hline Parameter & Estimated & Stand Error & t-Value \\
\hline \multicolumn{4}{|c|}{ The dependent variable is the natural log of transaction price } \\
\hline Intercept & 10.8817 & 0.0315 & $345.5206 * *$ \\
\hline \multicolumn{4}{|l|}{ Independent variables } \\
\hline Land area & 0.0006 & 0.0001 & $9.3171 * * *$ \\
\hline Building Area & 0.0004 & 0.0001 & $6.1404 * * *$ \\
\hline Property age & -0.0107 & 0.0006 & $-19.3177 * * *$ \\
\hline Number of floors & -0.0143 & 0.0012 & $-12.0566 * * *$ \\
\hline Fronting road width & 0.0045 & 0.0005 & $8.9741 * * *$ \\
\hline Z1: Zoning dummy (Commercial= 1 , Residential $=0$ ) & 0.0283 & 0.0123 & $2.3103 *$ \\
\hline S1: Structure type (Reinforced steel $=1$, Light steel frame, brick, stone $=0$ ) & -0.3989 & 0.0162 & $-24.6219 *$ \\
\hline R1: Positionning (Corner lot $=1$, Others $=0$ ) & 0.0313 & 0.0119 & $2.6207 *$ \\
\hline T1: Buiding type (apartments or town house $=1$, Store dwelling $=0$ ) & -0.2061 & 0.0163 & $-12.6382 *$ \\
\hline L1: Location (Urban $=1$, Suburban $=0$ ) & 0.1252 & 0.0117 & $10.6932 *$ \\
\hline A3: Rehabilitation status location (Whitin grant area $=1$, outside $=0$ ) & 0.1241 & 0.0247 & $5.0295^{*}$ \\
\hline Global & 0.305 & GWR & 0.51 \\
\hline adjusted $R^{2}$ & $30.30 \%$ & adjusted $\mathrm{R}^{2}$ & $50 \%$ \\
\hline Samples & 4,096 & Samples & 4,096 \\
\hline
\end{tabular}

Table 10: The stationarity for Model II

\begin{tabular}{|c|c|}
\hline Estimating stationarity of space variables (Model II) & p-Value \\
\hline Constant & 0.06 \\
\hline Land area & 0.65 \\
\hline Building Area & 0.14 \\
\hline Property age & $0.00000^{* * * *}$ \\
\hline Number of floors & 0.26 \\
\hline Fronting road width & 0.17 \\
\hline Z1: Zoning dummy (Commercial = 1, Residential =0) & 0.18 \\
\hline S1: Structure type (Reinforced steel $=1$, Light steel frame, brick, stone $=0$ ) & $0.00000 * * *$ \\
\hline R1: Positionning (Corner lot $=1$, Others $=0$ ) & $0.00000 * * *$ \\
\hline T1: Buiding type (apartments or town house $=1$, Store dwelling $=0$ ) & $0.00000^{* * *}$ \\
\hline L1: Location (Urban $=1$, Suburban $=0$ ) & $0.00000 * * *$ \\
\hline A3: Rehabilitation status location (Whitin grant area $=1$, outside $=0$ ) & $0.03000^{*}$ \\
\hline
\end{tabular}


Now, instead of producing a single global average variables estimate for each relationship, GWR produces a set of local parameter estimates that can be mapped below in Figure 1 and Figure 2 for $\mathrm{t}$ tests results.

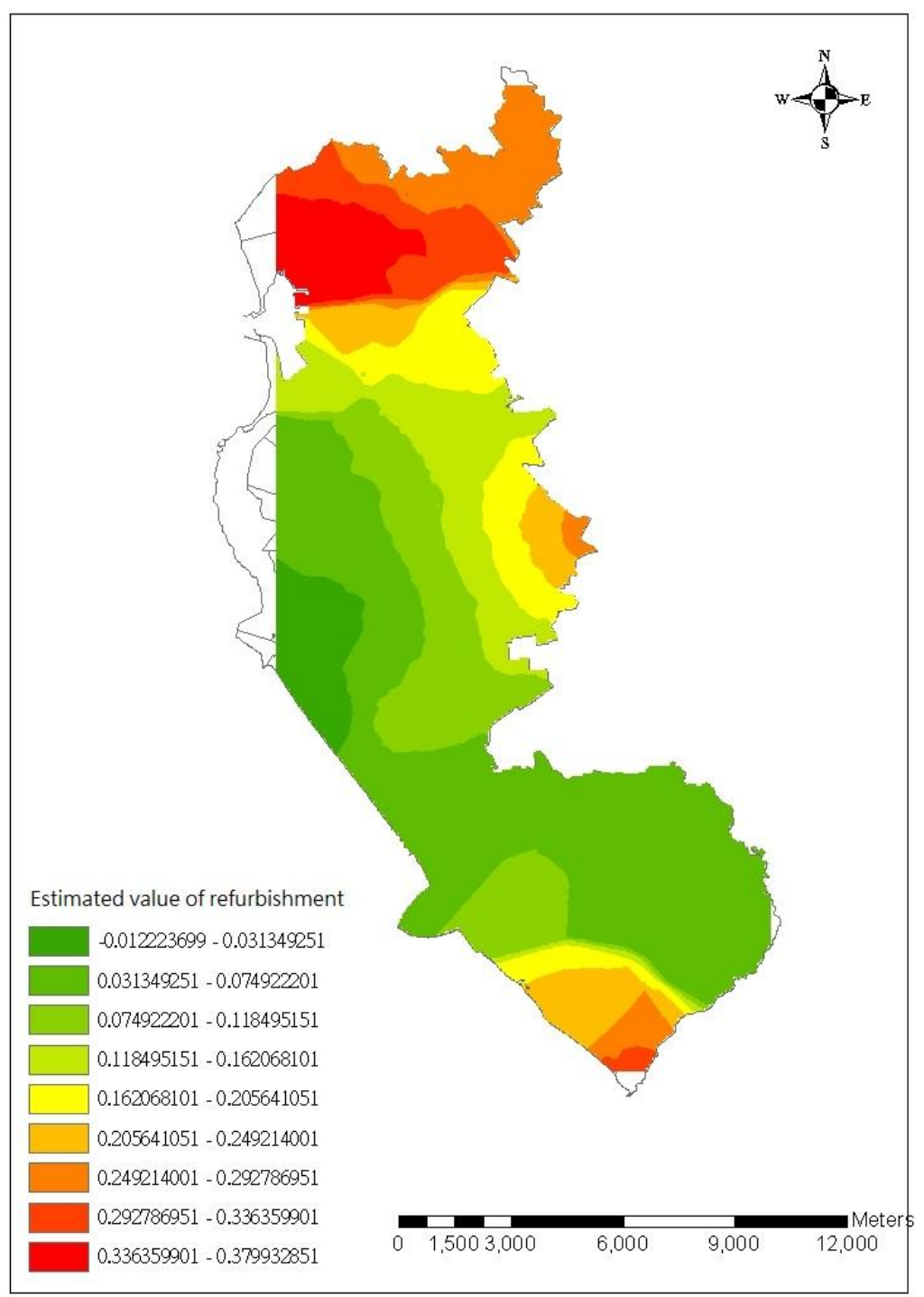

Figure 1: Mapping of the estimated value of refurbishment variables in Kaohsiung downtown 


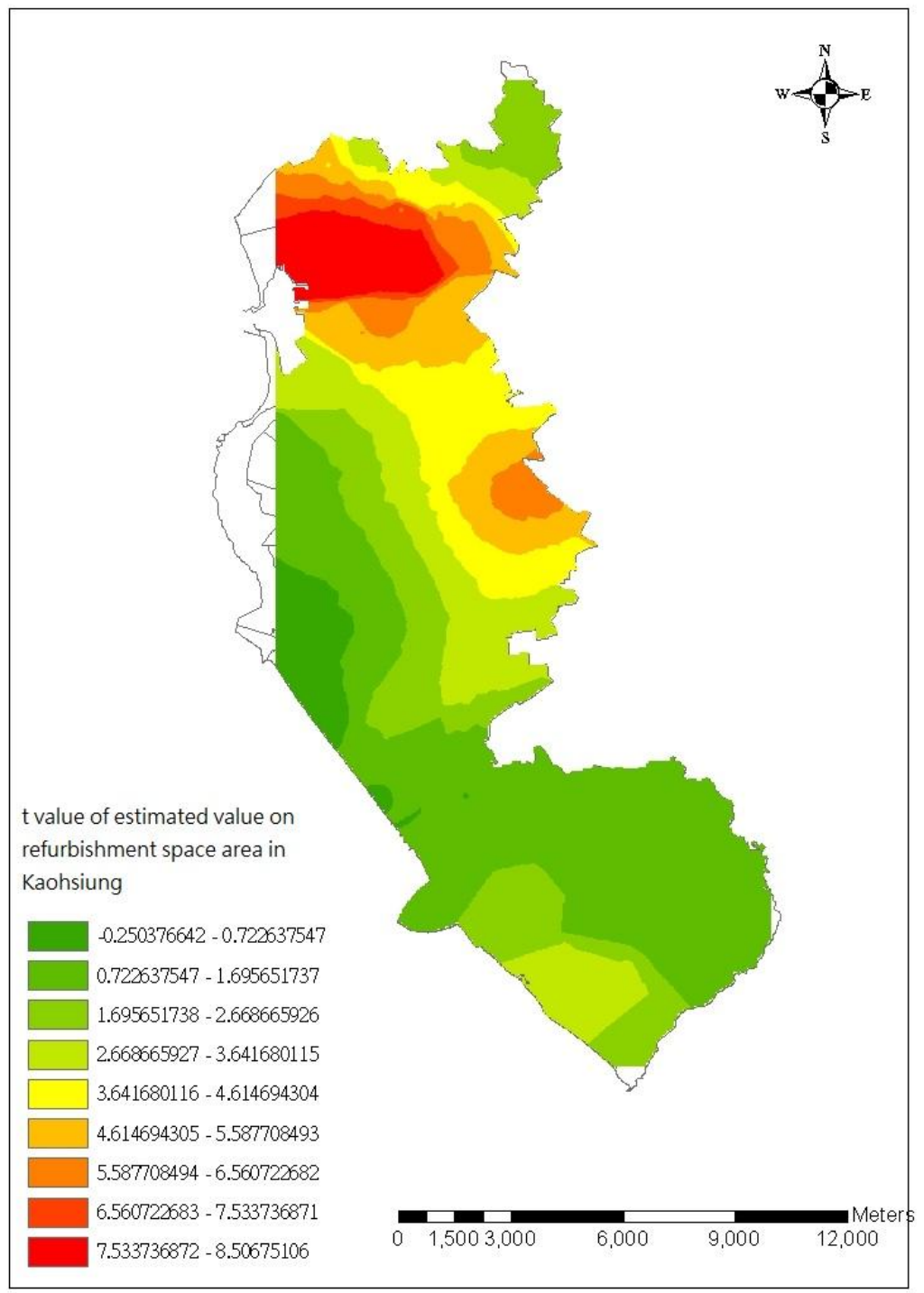

Figure 2: Mappingof the refurbishment variables by $\mathrm{t}$-value in Kaohsiung downtown 


\subsection{CONCLUSIONS}

The main question for this study was: "does proximity to a refurbished section of town or inclusion in a rehabilitation zone have any influence on transaction prices". The answer is in conformity with our basic intuition. Any significant improvement to the urban environment will have some favourable externality on surrounding properties. In fact, the immediate effects (from model I) are spreading further out (using variable A3 in model II) indicating that, contrary to a hypothesis formulated by Chau et.al. (2003), the surrounding sectors do not seem to be negatively impacted by the rehabilitation programme.

The reason for this difference may be due to the fact that in the Hong Kong case Chau et.al. (2003) are treating important urban renewal project that was unlikely to be repeated in surrounding neighbourhoods (thus reducing the option value of excluded properties) whereas in our case, the largely private equity financing model of refurbishment of individual building may in contrary - have increased option values of surrounding properties that could be the next targeted for similar support programmes.

The advantage of using the Geographical Weighted Regression models is to differentiate the effects spatially and to take into account variables non stationarities.

From the results of GWR, we find that spatial specific models improve the explanatory power of the model. Two spatial specificity variables are used in this treatment: proximity to the refurbishment focal point (A2) and inclusion within the designated rehabilitation zone (A3). The inclusion of both factors improves the performance $\left(\mathrm{R}^{2}\right.$ increases from $30.6 \%$ to $36.5 \%$ by the inclusion of $\mathrm{A} 2$ and then to $50 \%$ by the inclusion of $\mathrm{A} 3$ )

Furthermore, from figure 1, we observe that regression coefficients of rehabilitation are negatively correlated in southern ends of Yancheng District and Gushan District. Thus we confirm that, as demonstrated in previous studies, the benefits of public investments can be heterogeneous. This study is exploratory, and more detailed investigation and experimentation with different functional forms would be required. The result also reacts the refurbishment effects on housing price, especially on spatial effects. This paper demonstrates the potential advantage of GWR to improve mass valuation models. By using GWR model, it outperforms the spatial expansion method in terms of explanatory power and predictive accuracy in Taiwan.

\subsection{ACKNOWLEDGEMENT}

This research is supported through the financial support by the National Science Council in Taiwan (NSC98-2410-H-251-016).

\subsection{REFERENCES}

Achour-Fischer, D. (1980): Toward Fiscaltopia. The Respective Roles of State and Local Governments in Land Policy and Taxation, University of Southern California Law Center.

Brunsdon, C., Fotheringham, A.S \& Charlton, M.E. (1996): Geographically weighted regression: a method for exploring spatial no stationarity. Geographical Analysis, 28,281-298. 
B Huang. B Wu. M. Barry (2010), geographically and temporally weighted regression for modelling spatial- temporal variation in house prices, International Journal of Geographical Information Science, 24(3)

Benedetto Manganelli, Piergiuseppe ,Pontrandolfi, Antonello,Azzato, Beniamino Murgante (2014),"Using geographically weighted regression for housing market segmentation", International Journal of Business intelligence and Data Mining, Vol (9),2

Bitter, GF Mulligan, S Dall'erba (2007),'Incorporating spatial variation in housing attribute prices: a comparison of geographically weighted regression and the spatial expansion method", Journal of Geographical Systems, 9(1), 7-27

Chau, K.W., Leung, A.Y.T., Yiu, C.Y. and Wong, S.K. (2003): "Estimating the value enhancement effects of refurbishment", Facilities, 21(1\&2), 13-16.

Catherine Baumont (2009)," Spatial effects of urban public policies on housing values", Papers in Regional Science, 88(2), 301-326

Fotheringham, A.S \& Brunsdon, C. (1999): Local forms of spatial analysis. Geographical Analysis, 31, 340-358

Fotheringham, A.S., Brunsdon, C. \& Charlton, M.E. (1998): Geographically weighted regression: a natural evolution of the expansion method for spatial data analysis. Environment and Planning A, 30, 1905-1927.

Fotheringham, A.S., Charlton, M.E. \& Brunsdon, C. (1997): Measuring spatial variations in relationships with geographically weighted regression. In: M.M. Fischer \& A. Getis, Eds, Recent Developments in Spatial Analysis: Spatial Statistics, Behavioral Modelling and Computational Intelligence, Berlin: Springer, 60-80.

Haotian Zhong, Wei Li (2016),"Rail transit investment and property values: An old tale retold Transport Policy", Elsevier

Hongbo Du , Corinne Mulley (2006),"Relationship between transport accessibility and land value: Local model approach with geographically weighted regression", Transportation Research Record: Journal of the Transportation Research Board, 1977(1)

Jing Yao, A. Stewart Fotheringham (2016), "Local Spatiotemporal Modelling of House Prices: A Mixed Model Approach “, The Professional Geographer, 68(2), 189-201

K.W. Chau, S.K. Wong, A.Y.T. Leung. C.Y. Yiu ,"Estimating the value enhancement effects of refurbishment", Facilities, 21(1\&2), 13 - 19

Mohd Faris Dziauddin, Neil \& Powel, Seraphim Alvanides (2015), "Estimating the Effects of Light Rail Transit (LRT) System on Residential Property Values Using Geographically Weighted Regression (GWR)", Applied Spatial Analysis and Policy, 8(1), 1-25

Tammy Leonard, Lei Zhang, Christy Hoehner (2015), Variations in Park Facility Valuations across Neighbourhoods, Applied Spatial Analysis and Policy, 8(1), pp 45-67

Wadu Mesthrige, Jayantha, and Hei Lam Poon (2015), Assessing the impact of revitalized old industrial buildings on the value of surrounding properties: An empirical study. Facilities $33(3 \& 4), 245-261$

Wenjie Wu \& Guanpeng Dong (2014), "Valuing the "green" amenities in a spatial context", Journal of Regional Science, 54(4), 569-585

Yao Chen, Kayvan Karimi (2015),"Understanding the roles of urban configuration on spatial heterogeneity and submarket regionalization of house price pattern in a mix-scale hedonic model: The case of Shanghai, China", Proceeding of the 10th International Space Syntax Symposium 
Yau, Yung(2012), "Investigating the differences in the impacts of redevelopment and building rehabilitation on house prices: A Hong Kong case study", Journal of Building Survey. Appraisal \& Valuation ,1(1), 63-73.

Yung Yau, Kwong Wing Chau, Daniel Chi Wing, Ho Siu Kei Wong(2008), “An empirical study on the positive externality of building refurbishment", International Journal of Housing Markets and Analysis, 1(1), 19-32 